\title{
PATENT FORAMEN OVALE AND STROKE
}

\author{
Shunichi Homma, MD and Marco R. Di Tullio, MD \\ Columbia University, New York, NY
}

\section{SUMMARY}

The presence of a patent foramen ovale has been found to be associated with an increased risk of ischemic stroke of otherwise unknown origin (cryptogenic stroke). The present article will review the evidence regarding this association, the technical aspects of PFO detection, and the preventive options to decrease the risk of recurrent cerebral events.

\section{Frequency of PFO in the population}

The foramen ovale is a normal component of the fetal circulation that usually closes after birth because of the fusion between the two embryologic components of the atrial septum, the septum primum and septum secundum. In many individuals, a small communication persists into adult life, and is referred to as a patent foramen ovale (PFO). The frequency of a PFO in the population has been reported at $15 \%$ to $35 \%$ in autopsy studies [1-3] and appears to decrease with age[3]. In-vivo studies that have used transesophageal echocardiography (TEE) have reported a prevalence of PFO in the population very similar to that of the autopsy studies (24.3\%)[4]. The prevalence of PFO has been described as similar across different race-ethnic groups[5].

\section{Detection of PFO}

In its most common variety, a PFO is a virtual conduit located at the site of confluence of the septum primum and septum secundum, which opens whenever the pressure in the right atrium exceeds the pressure in the left atrium. Therefore, the diagnostic techniques for PFO detection are based on the direct visualization of the opening or of its functional consequence, the right-to-left shunt. The assessment is usually performed at rest and during maneuvers, such as the Valsalva maneuver or cough, which increase the pressure in the right-sided chambers of the heart and may therefore unmask a shunt not visible under resting conditions. The diagnostic techniques most commonly used for PFO detection are TEE, transthoracic echocardiography (TTE) and transcranial Doppler (TCD), performed with contrast injection to allow the visualization of any right-to-left shunt. The contrast material may be aerated and agitated saline solution or a polygelatine agent. For screening purposes, TTE or TCD are generally used. TEE is the gold standard for the diagnosis due to its higher diagnostic accuracy, but, due to its semi-invasive nature, is usually reserved to cases in which a better anatomic definition of the PFO is needed. With contrast TTE, the study is considered positive when any microbubble is seen in the left-sided chamber within three cardiac cycles after the contrast material fills the right-sided chambers (Figure 1). Contrast

Contact: Shunichi Homma, MD, Division of Cardiology, Columbia University, College of Physicians \& Surgeons, 630 West $168^{\text {th }}$ Street, New York, N.Y. 10032, Fax-: 212-305-9049, sh23@ columbia.edu.

Publisher's Disclaimer: This is a PDF file of an unedited manuscript that has been accepted for publication. As a service to our customers we are providing this early version of the manuscript. The manuscript will undergo copyediting, typesetting, and review of the resulting proof before it is published in its final citable form. Please note that during the production process errors may be discovered which could affect the content, and all legal disclaimers that apply to the journal pertain. 
TTE has been shown to have lower sensitivity for PFO detection than TEE (50-60\%) [6-9]. Recent advances in imaging technique have led to an improved sensitivity of TTE (80-90\%) $[10,11]$. Probably due to the lower sensitivity of TTE for small shunts, the prevalence of PFO by contrast TTE in the general population has reported to be lower than by TEE (14.9\% vs. $24.3 \%)[4,12]$.

Contrast TCD is also used to detect a PFO (Figure 2). The sensitivity of TCD has been shown to be slightly lower than that of TEE in some studies[7, 13], but essentially equivalent to it in others $[14,15]$.

TEE is considered the gold standard for the diagnosis of PFO. Its sensitivity and specificity have been reported to be essentially $100 \%[16]$. TEE also allows the direct visualization of the PFO opening in most patients (Figure 3), and therefore the direct measurement of the separation between septum primum and secundum as an indicator of PFO size. Also, TEE allows the direct visualization of the pulmonary veins, therefore resulting in a more accurate distinction between PFO and intrapulmonary shunt than possible by TTE or TCD.

Major complications resulting from the performance of TEE are rare $(0.2 \%$ in a published series) [17].

\section{Atrial Septal Aneurysm (ASA)}

An atrial septal aneurysm (ASA) is a protrusion of a segment of atrial septum into either atrial chamber. A protrusion of at least $10 \mathrm{~mm}$ with base of at least $10 \mathrm{~mm}$ is generally considered diagnostic of ASA [5, 18]. The prevalence of ASA in the population appears to be low (approximately 1-4\%) $[4,12,19]$. When present, an ASA is associated with a PFO in over $60 \%$ of cases $[18,20,21]$. TEE can identify the presence of an ASA very accurately (Figure 4). TTE can also detect an ASA, although with lower sensitivity than TEE[18, 20].

\section{PFO, ASA and stroke risk}

In the past twenty years, the association between PFO and cryptogenic strokes, which represent up to $40 \%$ of ischemic strokes[22], has been established. The present section will review the evidence supporting this association.

\section{Case-control studies}

The relationship between PFO and cryptogenic stroke was first described in patients younger than 55[23] or 40[24] years of age. The hypothesized stroke mechanism is paradoxical embolization, or the embolization to the systemic arterial circulation of thrombus originated in the venous circulation. Paradoxical embolization, whose occurrence is documented by the occasional detection of thrombus lodged in the PFO (figure 5), often remains a presumptive rather than a certain diagnosis.

The association between PFO and cryptogenic stroke in younger patients was confirmed in multiple studies with TTE or TEE [25-29]. Overall, younger stroke patients have a to 4-fold increase in PFO prevalence compared to stroke-free control subjects of same sex and age (Table 1A). The association has been more controversial in elderly subjects, in whom it has been invoked [27] or negated[30] [31]. Recently, a TEE study reaffirmed its existence in the older age group after adjustment for other stroke risk factors (odds ratio $3.00,95 \%$ confidence interval 1.73 to 5.23; $\mathrm{p}<0.001)$ [29]. The strength of the association was in fact similar to that observed in younger patients (odds ratio 3.70, 95\% confidence interval 1.42 to 9.65; $\mathrm{p}=0.008$ ) [29]. Combined results from studies in the elderly suggest the existence a 2fold increase in PFO prevalence in stroke patients compared to controls (Table 1B). 
Therefore, the association between PFO and cryptogenic stroke appears to exist in all age groups, although it may be stronger in younger individuals.

ASA has also been linked to an increased risk of ischemic stroke. ASA was significantly more frequent in patients with cryptogenic stroke than in controls (15\% vs 4\%; $<<0.05)$ [20]. However, a coexisting PFO is very often seen in patients with ASA (60-70\% of cases), and the PFO size tends to be larger in them [21, 32]. Therefore, the associated stroke risk may reflect the frequent coexistence of a PFO. However, the coexistence of the two abnormalities may be a stronger stroke risk factor than either condition alone. In a meta-analysis, the odds ratio for stroke was 1.83 for PFO alone and 2.35 for ASA alone, but 4.96 for their combination [31]. In stroke patients below age 55 treated with aspirin, the 4-year recurrent stroke rate was markedly higher (15.2\%) in those with combined PFO and ASA than in those with isolated PFO (2.3\%) or no PFO (4.2\%)[33]. Patients with PFO and ASA were shown to have more often multiple acute brain lesions, a hallmark of embolic mechanism, than patients with PFO alone (53\% vs. 17\%; $\mathrm{p}=0.01$ ) [34]. Other potential stroke mechanisms from an ASA include in situ thrombus formation, which is probably rare [18]; a predisposition to the development of atrial arrhythmias, which remains controversial [35, 36]; and left atrial dysfunction, a precursor of thrombus formation [37].

\section{Stroke Risk in the General Population}

The above data were obtained from case-control studies, therefore on individuals that had already had an event compared to stroke free-subjects of similar sex and age. This approach, although effective, suffers from an inherent risk of incomplete matching of cases and controls with regard to pertinent variables, and may therefore lead to biased results. Prospective studies do not suffer from those limitations, and two such studies examined the role of a PFO in the general population. In the Stroke Prevention: Assessment of Risk in a Community (SPARC) study, the stroke risk from cardiac embolic sources was investigated by TEE [4]. The prevalence of PFO was $24.3 \%$. Over a median follow-up of approximately five years, PFO was found not to be independently associated with increased risk of cerebrovascular events (hazard ratio 1.46, 95\% confidence interval 0.74-2.88). In the population-based Northern Manhattan Study (NOMAS), the presence of a PFO was sought by contrast TTE in 1,100 stroke-free individuals [12]. PFO prevalence was lower (14.9\%), reflecting the lower sensitivity of TTE. Over a mean follow up of almost seven years, PFO was not independently associated with ischemic stroke (hazard ratio $1.64,95 \%$ confidence interval 0.87-3.09). Therefore, the two studies, although on different populations and using different diagnostic tests, obtained remarkably similar results, with a slight, non-significant increase in stroke risk in individuals with PFO. Both studies hinted at an increased stroke risk from an ASA, but numbers were too small to allow any conclusions. The presence of both PFO and ASA did not increase the stroke risk in NOMAS, while the information was not available in SPARC. In general, these studies did not support the concept of an increased stroke risk from a PFO, although the possibility exists that a significant effect might have been observed with larger sample sizes or longer follow up durations.

\section{Possible associated factors}

Since the results of the population-based prospective studies did not confirm the result of the case-control studies, it appears that co-factors may exist that increase the risk associated, and may be more frequently present in stroke patients. This section will review some of the potential cofactors.

Anatomical variants-The size of the PFO (intended as the separation between septum primum and septum secundum on TEE) has been linked with stroke risk in multiple studies $[38,39]$. 
The degree of shunt through the PFO (inferred from the count of microbubbles in the left atrium) has also been associated with stroke risk, although this has not been confirmed in recent studies[40].

The role of a prominent Eustachian valve (the remnant of the valve that directs the blood from the inferior vena cava to the fossa ovalis of the atrial septum) as a co-factor in the stroke risk has been controversial. [39, 41]. An example of thrombus on Eustachian valve is presented in Figure 6. A Chiari's network (a web-like network of threads and fibers variably connecting the Eustachian valve to other atrial structures) is more frequently seen in patients with a PFO, ASA [21] and unexplained arterial embolism[42].

Hemodynamic factors-Conditions that increase the right atrial pressure have the potential to increase the degree of right-to-left shunt through the PFO, and therefore the likelihood of paradoxical embolization. Pulmonary embolism, right ventricular infarction and severe tricuspid regurgitation have been associated with increased shunting through a PFO.

Deep venous thrombosis (DVT)-The presence of a DVT can enhance the risk of paradoxical embolization through a PFO. An increased prevalence of DVT in cryptogenic stroke patients with a PFO was reported[43] but not confirmed[44]. The diagnostic technique used is also important, as pelvic vein thrombi, a potential source for paradoxical embolism [45], may be diagnosed by venography or MRI venogram, but are difficult to assess by ultrasound techniques.

Prothrombotic states-Blood hypercoagulability may facilitate thrombus formation in the vascular system, providing the substrate for paradoxical embolization. G20210A and factor V Leiden mutations have been reported in patients with cryptogenic stroke and PFO[46, 47]. One of these prothrombotic genotypes, more often G20210A mutation, was more frequently observed in young cryptogenic stroke patients than in age-matched controls (10.3\% vs. $2.5 \% ; \mathrm{p}=0.008)$, and increased the stroke risk by over 4-fold[48]. The combination of PFO and antiphospholipid antibodies did not significantly increase the stroke risk stroke in a multicenter study [49]. Recent surgery, trauma, or use of oral contraceptives may be associated with blood hypercoagulability and consequent greater potential for paradoxical embolization [50].

\section{Prevention of recurrent events}

The efforts to prevent recurrent events has focused on decreasing the likelihod of thrombosis or closing the PFO.

\section{Antithrombotic treatment}

The most frequently used antithrombotic drugs have been vitamin $\mathrm{K}$ inhibitors (such as warfarin) and antiplatelet agents, especially aspirin. From various meta-analyses, the rate of recurrent stroke or transient ischemic attack (TIA) whilst on these treatments was 4 events/ 100 person-years [51], and almost 5 events/100 person-years when death was also included [52]. In most studies, the treatment was not randomized. The only trial with randomized treatment assignment was the Patent Foramen Ovale in Cryptogenic Stroke study (PICSS), a TEE-based substudy of the Warfarin Aspirin Recurrent Stroke Study (WARSS), which randomized patients with non-cardioembolic stroke to aspirin $325 \mathrm{mg}$ or warfarin (target INR 1.4 to 2.8) [53]. In PICSS, 630 patients underwent TEE early after stroke. Over 2 years of follow-up, no significant differences in rates of recurrent stroke and death were observed between patients with and without a PFO (hazard ratio $0.96,95 \%$ confidence interval 0.62 to 1.48 ), even in patients with cryptogenic stroke (hazard ratio $1.17,95 \%$ confidence interval 
0.60 to 2.37) [54]. Similar results had been previously obtained in two studies in which the treatment was not randomized (La Sapienza study, 86 cryptogenic stroke patients treated with aspirin, warfarin, both or neither)[55] or consisted of only aspirin (PFO/ASA French study, 581 stroke patients below age 55)[33]. No significant differences in annual rates of stroke or death was reported between stroke patients with and without a PFO (3.7\% vs. $4.5 \%$ in La Sapienza study; $1.5 \%$ vs. $1.8 \%$ in the PFO/ASA French study). The French study documented a higher annual event rate $(3.7 \%)$ for patients with both PFO and ASA, raising the question that aspirin may not be sufficient protection in those patients. In PICSS, however, the combination of PFO and ASA did not carry an increased risk of recurrent events compared with neither condition (hazard ratio 1.04, 95\% confidence interval 0.51 to 2.12). This finding was confirmed by the CODICIA study on 200 stroke patients with PFO treated with warfarin or aspirin[40]. The presence of larger shunt was also not found to significantly affect the risk of recurrent events in PICSS [54] or CODICIA[40].

It therefore appears that antithrombotic treatment reduces the risk of recurrent events in stroke patients with a PFO to the level of stroke patients without it. By combining the data of PICSS, La Sapienza and PFO/ASA studies, the hazard ratio of PFO for recurrent stroke and death is 0.95 [56]. Whilst conclusive data are not available on the relative efficacy of warfarin and aspirin treatment, the event rates observed in PICSS did not suggest a definite advantage for either treatment.

\section{PFO closure}

\section{Surgery}

Surgical PFO closure was initially performed in selected cryptogenic stroke patients, and has become infrequent since the introduction of percutaneous closure devices. A low incidence of recurrent cerebrovascular events was reported after surgical closure in younger patients [57, 58], but not in older ones[57]. A meta-analysis on 161 patients (mean age 43 years) reported an annual risk of recurrent stroke or death of $0.85 \%$ (95\% CI, $0.10-3.07 \%$ )[52].

PFO closure is sometimes performed prophylactically in patients undergoing open heart surgery for other indications, but this practice is questioned. A study on over 13,000 cardiac operations showed no significant differences in perioperative stroke ( $2.3 \%$ vs. $2.3 \%$; $\mathrm{p}=0.84$ ) and in-hospital death $(3.4 \%$ vs. $2.6 \%$; $\mathrm{p}=0.11)$ between patients with or without a PFO; however, patients who had their PFO surgically closed experienced a 2.5 -fold increase in the risk of in-hospital stroke compared with those who did not ( $2.8 \%$ vs. $1.2 \%$; $\mathrm{p}=0.04)$, and showed no long-term survival benefit over a mean follow-up of 5.6 years[59].

\section{Transcatheter closure}

The introduction of percuteaneous closure devices has offered a less invasive alternative for closing a PFO. An example of PFO closure is shown in Figure 7. Data on the efficacy of these devices have come from case series and non-randomized studies. In a pooled analysis of studies published until 2004[52], the combined rate of recurrent stroke, death or TIA for PFO closure was 2.95 events/100 person-years. As devices have been improved, the incidence of recurrent events has decreased. In 131 patients, no recurrent embolic events were reported over a mean follow-up of 30 months[60]. Complications from device implantation have also decreased. In a meta-analysis of 1,355 patients, major complications such as death, major hemorrhage, cardiac tamponade and fatal pulmonary emboli were reported in approximately $1.5 \%$ [61]. Other complications such as atrial arrhythmias, device arm fractures, embolization or thrombosis, EKG changes, and arterio-venous fistula formation were observed in 7.9\%[61]. In a multicenter European study on 430 patients, periprocedural complications occurred in $11.5 \%$ of patients, $0.2 \%$ of which defined as major[62]. 
Transcatheter PFO closure may cause microembolization to the brain. Transient microembolic signals were detected by TCD in 28 of 29 patients during the procedure [63]. Repeat brain MRI documented new microembolic lesions after PFO closure in 3 of 35 subjects $(8.6 \%)[64]$.

Atrial fibrillation is relatively frequent after PFO closure, with an annual incidence of $2.5 \%$, which appears not related to device type or size [65].

\section{Antithrombotic treatment versus PFO closure}

Several randomized trials comparing PFO closure and antithrombotic treatment are ongoing, but the first results are not expected for at least another year [66]. So far, the patient populations in studies that have looked at PFO closure and studies that have examined antithrombotic treatment have differed. In general, patients in PFO closure studies tended to be younger and have higher frequency of previous thromboembolic events, whereas patients in the medical treatment studies tended to have higher frequencies of traditional stroke risk factors such as diabetes and cigarette smoking [61]. In 308 cryptogenic stroke patients with PFO treated medically (158 patients) or with PFO closure (150 patients), recurrent stroke or TIA tended to be less frequent in the closure group ( $7.8 \%$ vs. $22.2 \% ; \mathrm{p}=0.08 ; 95 \%$ CI 0.23 to 1.11), especially in patients with multiple cerebrovascular events at baseline [67]. As treatment was not randomized, patients with larger PFOs or multiple cerebrovascular events were more frequently assigned to PFO closure.

Because of the lack of data from randomized clinical trials, the treatment choice has been empirical. Supporters of PFO closure deem the available data strong enough not to withhold a potentially life-saving treatment while awaiting the results of randomized clinical trials[68]. Supporters of medical treatment argue that such treatment has been proven to essentially eliminate the PFO-related risk of stroke, and that a therapeutic paradigm shift such as PFO closure in stroke patients should only be entertained after evidence of its superiority has been proven by randomized trials[69]. The 2006 AHA/ASA guidelines for the prevention of stroke in patients with ischemic stroke or TIA deemed the available evidence insufficient to recommend PFO closure in patients with a first stroke[70]. Aspirin treatment was considered adequate in most stroke patients, with warfarin treatment recommended instead in case of coexisting DVT or prothrombotic state. The guidelines recommended to consider PFO closure in patients with recurrent cryptogenic stroke despite medical therapy[70].

\section{Conclusion}

Although the association between PFO and increased risk of stroke has been established, the role of a PFO as a stroke risk factor in the general population has not been confirmed. No preventive treatment is therefore necessary in individuals with an incidentally detected PFO. In stroke patients, treatment with antiplatelet agents (aspirin) appears to confer sufficient protection against recurrent events. Systemic anticoagulation should be preferred in patients with coexisting deep venous thrombosis or prothrombotic conditions. While awaiting the results of randomized trials, PFO closure appears indicated in patients with contraindications to medical treatment, or who experience recurrent events whilst on it. Further research is necessary to establish the optimal preventive treatment in patients with the more infrequent combination of ASA and PFO. Finally, a better understanding of co-factors that may increase the PFO-related stroke risk may allow a more rational and targeted approach to preventing recurrent embolic events. 


\section{Reference List}

1. Penther P. Patent foramen ovale: an anatomical study. Apropos of 500 consecutive autopsies. Arch Mal Coeur Vaiss. 1994 Jan; 87(1):15-21. [PubMed: 7811147]

2. Schroeckenstein RF, Wasenda GJ, Edwards JE. Valvular competent patent foramen ovale in adults. Minn Med. 1972 Jan; 55(1):11-3. [PubMed: 5009217]

3. Hagen PT, Scholz DG, Edwards WD. Incidence and size of patent foramen ovale during the first 10 decades of life: an autopsy study of 965 normal hearts. Mayo Clin Proc. 1984 Jan; 59(1):17-20. [PubMed: 6694427]

4. Meissner I, Khandheria BK, Heit JA, Petty GW, Sheps SG, Schwartz GL, Whisnant JP, Wiebers DO, Covalt JL, Petterson TM, Christianson TJ, Agmon Y. Patent foramen ovale: innocent or guilty? Evidence from a prospective population-based study. J Am Coll Cardiol. 2006 Jan 17; 47(2):440-5. [PubMed: 16412874]

5. Rodriguez CJ, Homma S, Sacco RL, Di Tullio MR, Sciacca RR, Mohr JP. Race-ethnic differences in patent foramen ovale, atrial septal aneurysm, and right atrial anatomy among ischemic stroke patients. Stroke. 2003 Sep; 34(9):2097-102. [PubMed: 12920255]

6. Teague SM, Sharma MK. Detection of paradoxical cerebral echo contrast embolization by transcranial Doppler ultrasound. Stroke. 1991 Jun; 22(6):740-5. [PubMed: 2057972]

7. Di Tullio M, Sacco RL, Venketasubramanian N, Sherman D, Mohr JP, Homma S. Comparison of diagnostic techniques for the detection of a patent foramen ovale in stroke patients. Stroke. 1993 Jul; 24(7):1020-4. [PubMed: 8322376]

8. Karnik R, Stollberger C, Valentin A, Winkler WB, Slany J. Detection of patent foramen ovale by transcranial contrast Doppler ultrasound. Am J Cardiol. 1992 Feb 15; 69(5):560-2. [PubMed: 1736625]

9. Di Tullio M, Sacco RL, Massaro A, Venketasubramanian N, Sherman D, Hoffmann M, Mohr JP, Homma S. Transcranial Doppler with contrast injection for the detection of patent foramen ovale in stroke patients. Int J Card Imaging. 1993 Mar; 9(1):1-5. [PubMed: 8491996]

10. Clarke NR, Timperley J, Kelion AD, Banning AP. Transthoracic echocardiography using second harmonic imaging with Valsalva manoeuvre for the detection of right to left shunts. Eur $\mathrm{J}$ Echocardiogr. 2004 Jun; 5(3):176-81. [PubMed: 15147659]

11. Daniels C, Weytjens C, Cosyns B, Schoors D, de SJ, Paelinck B, Muyldermans L, Van CG. Second harmonic transthoracic echocardiography: the new reference screening method for the detection of patent foramen ovale. Eur J Echocardiogr. 2004 Dec; 5(6):449-52. [PubMed: 15556821]

12. Di Tullio MR, Sacco RL, Sciacca RR, Jin Z, Homma S. Patent foramen ovale and the risk of ischemic stroke in a multiethnic population. J Am Coll Cardiol. 2007 Feb 20; 49(7):797-802. [PubMed: 17306710]

13. Job FP, Ringelstein EB, Grafen Y, Flachskampf FA, Doherty C, Stockmanns A, Hanrath P. Comparison of transcranial contrast Doppler sonography and transesophageal contrast echocardiography for the detection of patent foramen ovale in young stroke patients. Am $\mathrm{J}$ Cardiol. 1994 Aug 15; 74(4):381-4. [PubMed: 7914717]

14. Nemec JJ, Marwick TH, Lorig RJ, Davison MB, Chimowitz MI, Litowitz H, Salcedo EE. Comparison of transcranial Doppler ultrasound and transesophageal contrast echocardiography in the detection of interatrial right-to-left shunts. Am J Cardiol. 1991 Dec 1; 68(15):1498-502. [PubMed: 1746433]

15. Klotzsch C, Janssen G, Berlit P. Transesophageal echocardiography and contrast-TCD in the detection of a patent foramen ovale: experiences with 111 patients. Neurology. 1994 Sep; 44(9): 1603-6. [PubMed: 7936282]

16. Schneider B, Zienkiewicz T, Jansen V, Hofmann T, Noltenius H, Meinertz T. Diagnosis of patent foramen ovale by transesophageal echocardiography and correlation with autopsy findings. Am J Cardiol. 1996 Jun 1; 77(14):1202-9. [PubMed: 8651096]

17. Daniel WG, Erbel R, Kasper W, Visser CA, Engberding R, Sutherland GR, Grube E, Hanrath P, Maisch B, Dennig K. Safety of transesophageal echocardiography. A multicenter survey of 10,419 examinations. Circulation. 1991 Mar; 83(3):817-21. [PubMed: 1999032] 
18. Mugge A, Daniel WG, Angermann C, Spes C, Khandheria BK, Kronzon I, Freedberg RS, Keren A, Denning K, Engberding R. Atrial septal aneurysm in adult patients. A multicenter study using transthoracic and transesophageal echocardiography. Circulation. 1995 Jun 1; 91(11):2785-92. [PubMed: 7758185]

19. Meissner I, Whisnant JP, Khandheria BK, Spittell PC, O'Fallon WM, Pascoe RD, Enriquez-Sarano M, Seward JB, Covalt JL, Sicks JD, Wiebers DO. Prevalence of potential risk factors for stroke assessed by transesophageal echocardiography and carotid ultrasonography: the SPARC study. Stroke Prevention: Assessment of Risk in a Community. Mayo Clin Proc. 1999 Sep; 74(9):862-9. [PubMed: 10488786]

20. Pearson AC, Nagelhout D, Castello R, Gomez CR, Labovitz AJ. Atrial septal aneurysm and stroke: a transesophageal echocardiographic study. J Am Coll Cardiol. 1991 Nov 1; 18(5):1223-9. [PubMed: 1918699]

21. Homma S, Sacco RL, Di Tullio MR, Sciacca RR, Mohr JP. Atrial anatomy in non-cardioembolic stroke patients: effect of medical therapy. J Am Coll Cardiol. 2003 Sep 17; 42(6):1066-72. [PubMed: 13678932]

22. Sacco RL, Ellenberg JH, Mohr JP, Tatemichi TK, Hier DB, Price TR, Wolf PA. Infarcts of undetermined cause: the NINCDS Stroke Data Bank. Ann Neurol. 1989 Apr; 25(4):382-90. [PubMed: 2712533]

23. Lechat P, Mas JL, Lascault G, Loron P, Theard M, Klimczac M, Drobinski G, Thomas D, Grosgogeat Y. Prevalence of patent foramen ovale in patients with stroke. N Engl J Med. 1988 May 5; 318(18):1148-52. [PubMed: 3362165]

24. Webster MW, Chancellor AM, Smith HJ, Swift DL, Sharpe DN, Bass NM, Glasgow GL. Patent foramen ovale in young stroke patients. Lancet. 1988 Jul 2; 2(8601):11-2. [PubMed: 2898621]

25. Cabanes L, Mas JL, Cohen A, Amarenco P, Cabanes PA, Oubary P, Chedru F, Guerin F, Bousser $\mathrm{MG}$, de RJ. Atrial septal aneurysm and patent foramen ovale as risk factors for cryptogenic stroke in patients less than 55 years of age. A study using transesophageal echocardiography. Stroke. 1993 Dec; 24(12):1865-73. [PubMed: 8248969]

26. de Belder MA, Tourikis L, Leech G, Camm AJ. Risk of patent foramen ovale for thromboembolic events in all age groups. Am J Cardiol. 1992 May 15; 69(16):1316-20. [PubMed: 1585866]

27. Di Tullio M, Sacco RL, Gopal A, Mohr JP, Homma S. Patent foramen ovale as a risk factor for cryptogenic stroke. Ann Intern Med. 1992 Sep 15; 117(6):461-5. [PubMed: 1503349]

28. Hausmann D, Mugge A, Becht I, Daniel WG. Diagnosis of patent foramen ovale by transesophageal echocardiography and association with cerebral and peripheral embolic events. Am J Cardiol. 1992 Sep 1; 70(6):668-72. [PubMed: 1510018]

29. Handke M, Harloff A, Olschewski M, Hetzel A, Geibel A. Patent foramen ovale and cryptogenic stroke in older patients. N Engl J Med. 2007 Nov 29; 357(22):2262-8. [PubMed: 18046029]

30. Jones EF, Calafiore P, Donnan GA, Tonkin AM. Evidence that patent foramen ovale is not a risk factor for cerebral ischemia in the elderly. Am J Cardiol. 1994 Sep 15; 74(6):596-9. [PubMed: 8074044]

31. Overell JR, Bone I, Lees KR. Interatrial septal abnormalities and stroke: a meta-analysis of casecontrol studies. Neurology. 2000 Oct 24; 55(8):1172-9. [PubMed: 11071496]

32. Fox ER, Picard MH, Chow CM, Levine RA, Schwamm L, Kerr AJ. Interatrial septal mobility predicts larger shunts across patent foramen ovales: an analysis with transmitral Doppler scanning. Am Heart J. 2003 Apr; 145(4):730-6. [PubMed: 12679772]

33. Mas JL, Arquizan C, Lamy C, Zuber M, Cabanes L, Derumeaux G, Coste J. Recurrent cerebrovascular events associated with patent foramen ovale, atrial septal aneurysm, or both. N Engl J Med. 2001 Dec 13; 345(24):1740-6. [PubMed: 11742048]

34. Bonati LH, Kessel-Schaefer A, Linka AZ, Buser P, Wetzel SG, Radue EW, Lyrer PA, Engelter ST. Diffusion-weighted imaging in stroke attributable to patent foramen ovale: significance of concomitant atrial septum aneurysm. Stroke. 2006 Aug; 37(8):2030-4. [PubMed: 16809562]

35. Berthet K, Lavergne T, Cohen A, Guize L, Bousser MG, Le Heuzey JY, Amarenco P. Significant association of atrial vulnerability with atrial septal abnormalities in young patients with ischemic stroke of unknown cause. Stroke. 2000 Feb; 31(2):398-403. [PubMed: 10657412] 
36. Kizer JR. Patent foramen ovale and cryptogenic stroke. Am J Med. 2007 Dec.120(12):e13. [PubMed: 18060903]

37. Rigatelli G, Aggio S, Cardaioli P, Braggion G, Giordan M, Dell'avvocata F, Chinaglia M, Rigatelli G, Roncon L, Chen JP. Left atrial dysfunction in patients with patent foramen ovale and atrial septal aneurysm: an alternative concurrent mechanism for arterial embolism? JACC Cardiovasc Interv. 2009 Jul; 2(7):655-62. [PubMed: 19628189]

38. Homma S, Di Tullio MR, Sacco RL, Mihalatos D, Li MG, Mohr JP. Characteristics of patent foramen ovale associated with cryptogenic stroke. A biplane transesophageal echocardiographic study. Stroke. 1994 Mar; 25(3):582-6. [PubMed: 8128511]

39. Goel SS, Tuzcu EM, Shishehbor MH, de Oliveira EI, Borek PP, Krasuski RA, Rodriguez LL, Kapadia SR. Morphology of the patent foramen ovale in asymptomatic versus symptomatic (stroke or transient ischemic attack) patients. Am J Cardiol. 2009 Jan 1; 103(1):124-9. [PubMed: 19101242]

40. Serena J, Marti-Fabregas J, Santamarina E, Rodriguez JJ, Perez-Ayuso MJ, Masjuan J, Segura T, Gallego J, Davalos A. Recurrent stroke and massive right-to-left shunt: results from the prospective Spanish multicenter (CODICIA) study. Stroke. 2008 Dec; 39(12):3131-6. [PubMed: 18818401]

41. Schuchlenz HW, Saurer G, Weihs W, Rehak P. Persisting eustachian valve in adults: relation to patent foramen ovale and cerebrovascular events. J Am Soc Echocardiogr. 2004 Mar; 17(3):2313. [PubMed: 14981420]

42. Schneider B, Hofmann T, Justen MH, Meinertz T. Chiari's network: normal anatomic variant or risk factor for arterial embolic events? J Am Coll Cardiol. 1995 Jul; 26(1):203-10. [PubMed: 7797753]

43. Stollberger C, Slany J, Schuster I, Leitner H, Winkler WB, Karnik R. The prevalence of deep venous thrombosis in patients with suspected paradoxical embolism. Ann Intern Med. 1993 Sep 15; 119(6):461-5. [PubMed: 8357111]

44. Ranoux D, Cohen A, Cabanes L, Amarenco P, Bousser MG, Mas JL. Patent foramen ovale: is stroke due to paradoxical embolism? Stroke. 1993 Jan; 24(1):31-4. [PubMed: 8418547]

45. Cramer SC, Rordorf G, Maki JH, Kramer LA, Grotta JC, Burgin WS, Hinchey JA, Benesch C, Furie KL, Lutsep HL, Kelly E, Longstreth WT Jr. Increased pelvic vein thrombi in cryptogenic stroke: results of the Paradoxical Emboli from Large Veins in Ischemic Stroke (PELVIS) study. Stroke. 2004 Jan; 35(1):46-50. [PubMed: 14657451]

46. Pezzini A, Del ZE, Magoni M, Costa A, Archetti S, Grassi M, Akkawi NM, Albertini A, Assanelli D, Vignolo LA, Padovani A. Inherited thrombophilic disorders in young adults with ischemic stroke and patent foramen ovale. Stroke. 2003 Jan; 34(1):28-33. [PubMed: 12511746]

47. Karttunen V, Hiltunen L, Rasi V, Vahtera E, Hillbom M. Factor V Leiden and prothrombin gene mutation may predispose to paradoxical embolism in subjects with patent foramen ovale. Blood Coagul Fibrinolysis. 2003 Apr; 14(3):261-8. [PubMed: 12695749]

48. Botto N, Spadoni I, Giusti S, it-Ali L, Sicari R, Andreassi MG. Prothrombotic mutations as risk factors for cryptogenic ischemic cerebrovascular events in young subjects with patent foramen ovale. Stroke. 2007 Jul; 38(7):2070-3. [PubMed: 17525392]

49. Rajamani K, Chaturvedi S, Jin Z, Homma S, Brey RL, Tilley BC, Sacco RL, Thompson JL, Mohr JP, Levine SR. Patent foramen ovale, cardiac valve thickening, and antiphospholipid antibodies as risk factors for subsequent vascular events: the PICSS-APASS study. Stroke. 2009 Jul; 40(7): 2337-42. [PubMed: 19498198]

50. Meacham RR III, Headley AS, Bronze MS, Lewis JB, Rester MM. Impending paradoxical embolism. Arch Intern Med. 1998 Mar 9; 158(5):438-48. [PubMed: 9508221]

51. Almekhlafi MA, Wilton SB, Rabi DM, Ghali WA, Lorenzetti DL, Hill MD. Recurrent cerebral ischemia in medically treated patent foramen ovale: a meta-analysis. Neurology. $2009 \mathrm{Jul} 14$; 73(2):89-97. [PubMed: 19439720]

52. Homma S, Sacco RL. Patent foramen ovale and stroke. Circulation. 2005 Aug 16; 112(7):1063-72. [PubMed: 16103257]

53. Mohr JP, Thompson JL, Lazar RM, Levin B, Sacco RL, Furie KL, Kistler JP, Albers GW, Pettigrew LC, Adams HP Jr, Jackson CM, Pullicino P. A comparison of warfarin and aspirin for 
the prevention of recurrent ischemic stroke. N Engl J Med. 2001 Nov 15; 345(20):1444-51. [PubMed: 11794192]

54. Homma S, Sacco RL, Di Tullio MR, Sciacca RR, Mohr JP. Effect of medical treatment in stroke patients with patent foramen ovale: patent foramen ovale in Cryptogenic Stroke Study. Circulation. 2002 Jun 4; 105(22):2625-31. [PubMed: 12045168]

55. De Castro S, Cartoni D, Fiorelli M, Rasura M, Anzini A, Zanette EM, Beccia M, Colonnese C, Fedele F, Fieschi C, Pandian NG. Morphological and functional characteristics of patent foramen ovale and their embolic implications. Stroke. 2000 Oct; 31(10):2407-13. [PubMed: 11022072]

56. Messe SR, Silverman IE, Kizer JR, Homma S, Zahn C, Gronseth G, Kasner SE. Practice parameter: recurrent stroke with patent foramen ovale and atrial septal aneurysm: report of the Quality Standards Subcommittee of the American Academy of Neurology. Neurology. 2004 Apr 13; 62(7):1042-50. [PubMed: 15078999]

57. Homma S, Di Tullio MR, Sacco RL, Sciacca RR, Smith C, Mohr JP. Surgical closure of patent foramen ovale in cryptogenic stroke patients. Stroke. 1997 Dec; 28(12):2376-81. [PubMed: 9412617]

58. Dearani JA, Ugurlu BS, Danielson GK, Daly RC, McGregor CG, Mullany CJ, Puga FJ, Orszulak TA, Anderson BJ, Brown RD Jr, Schaff HV. Surgical patent foramen ovale closure for prevention of paradoxical embolism-related cerebrovascular ischemic events. Circulation. 1999 Nov 9; 100(19 Suppl):II171-II175. [PubMed: 10567299]

59. Krasuski RA, Hart SA, Allen D, Qureshi A, Pettersson G, Houghtaling PL, Batizy LH, Blackstone E. Prevalence and repair of intraoperatively diagnosed patent foramen ovale and association with perioperative outcomes and long-term survival. JAMA. 2009 Jul 15; 302(3):290-7. [PubMed: 19602688]

60. Slavin L, Tobis JM, Rangarajan K, Dao C, Krivokapich J, Liebeskind DS. Five-year experience with percutaneous closure of patent foramen ovale. Am J Cardiol. 2007 May 1; 99(9):1316-20. [PubMed: 17478165]

61. Khairy P, O’Donnell CP, Landzberg MJ. Transcatheter closure versus medical therapy of patent foramen ovale and presumed paradoxical thromboemboli: a systematic review. Ann Intern Med. 2003 Nov 4; 139(9):753-60. [PubMed: 14597460]

62. Spies C, Timmermanns I, Reissmann U, van EJ, Schrader R. Patent foramen ovale closure with the Intrasept occluder: Complete 6-56 months follow-up of 247 patients after presumed paradoxical embolism. Catheter Cardiovasc Interv. 2008 Feb 15; 71(3):390-5. [PubMed: 18288745]

63. Morandi E, Anzola GP, Casilli F, Onorato E. Silent brain embolism during transcatheter closure of patent foramen ovale: a transcranial Doppler study. Neurol Sci. 2006 Nov; 27(5):328-31. [PubMed: 17122942]

64. Dorenbeck U, Simon B, Skowasch D, Stusser C, Gockel A, Schild HH, Urbach H, Bauriedel G. Cerebral embolism with interventional closure of symptomatic patent foramen ovale: an MRIbased study using diffusion-weighted imaging. Eur J Neurol. 2007 Apr; 14(4):451-4. [PubMed: 17388997]

65. Spies C, Khandelwal A, Timmermanns I, Schrader R. Incidence of atrial fibrillation following transcatheter closure of atrial septal defects in adults. Am J Cardiol. 2008 Oct 1; 102(7):902-6. [PubMed: 18805119]

66. Meier B. Catheter-based closure of the patent foramen ovale. Circulation. 2009 Nov 3; 120(18): 1837-41. [PubMed: 19884482]

67. Windecker S, Wahl A, Nedeltchev K, Arnold M, Schwerzmann M, Seiler C, Mattle HP, Meier B. Comparison of medical treatment with percutaneous closure of patent foramen ovale in patients with cryptogenic stroke. J Am Coll Cardiol. 2004 Aug 18; 44(4):750-8. [PubMed: 15312853]

68. Windecker S, Meier B. Is closure recommended for patent foramen ovale and cryptogenic stroke? Patent foramen ovale and cryptogenic stroke: to close or not to close? Closure: what else! Circulation. 2008 Nov 4; 118(19):1989-98. [PubMed: 18981313]

69. Messe SR, Kasner SE. Is closure recommended for patent foramen ovale and cryptogenic stroke? Patent foramen ovale in cryptogenic stroke: not to close. Circulation. 2008 Nov 4; 118(19):19992004. [PubMed: 18981314] 
70. Sacco RL, Adams R, Albers G, Alberts MJ, Benavente O, Furie K, Goldstein LB, Gorelick P, Halperin J, Harbaugh R, Johnston SC, Katzan I, Kelly-Hayes M, Kenton EJ, Marks M, Schwamm LH, Tomsick T. Guidelines for prevention of stroke in patients with ischemic stroke or transient ischemic attack: a statement for healthcare professionals from the American Heart Association/ American Stroke Association Council on Stroke: co-sponsored by the Council on Cardiovascular Radiology and Intervention: the American Academy of Neurology affirms the value of this guideline. Stroke. 2006 Feb; 37(2):577-617. [PubMed: 16432246] 


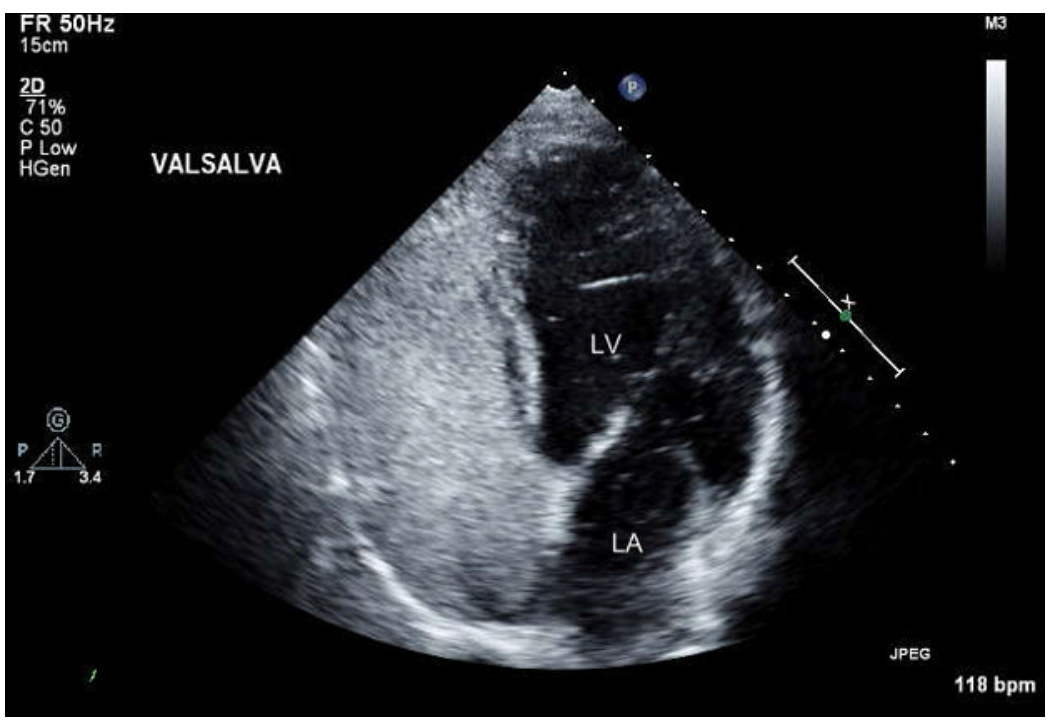

Figure 1.

Example of PFO detection by transthoracic echocardiography (TTE) with contrast injection. Microbubbles are visualized filling the right-sided chambers and into the left atrium (LA) and left ventricle (LV). 


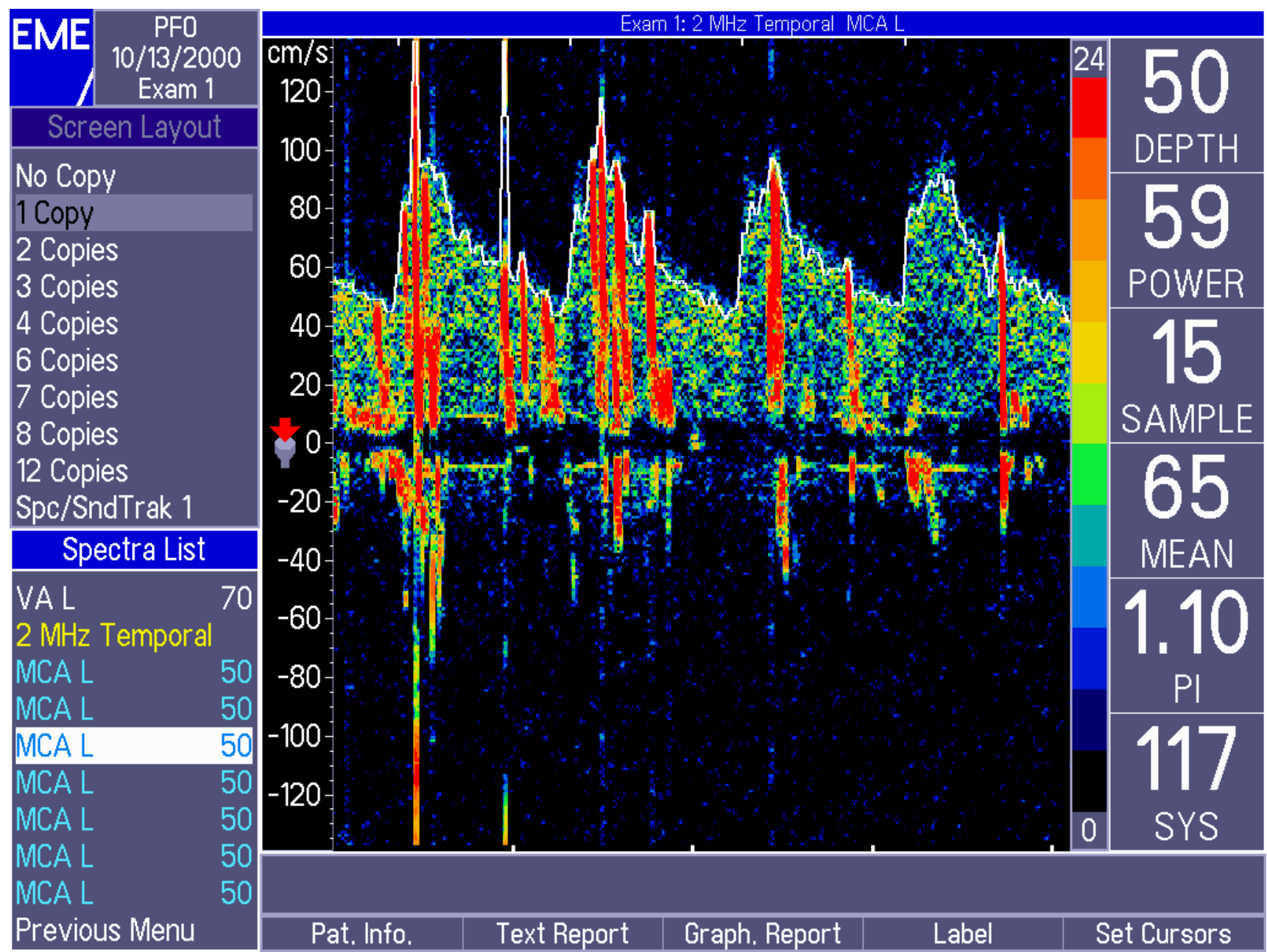

Figure 2.

Detection of microbubbles by transcranial Doppler (TCD) in the middle cerebral artery of a patient with a PFO. Microbubbles are visualized as spikes superimposed to the normal blood flow 


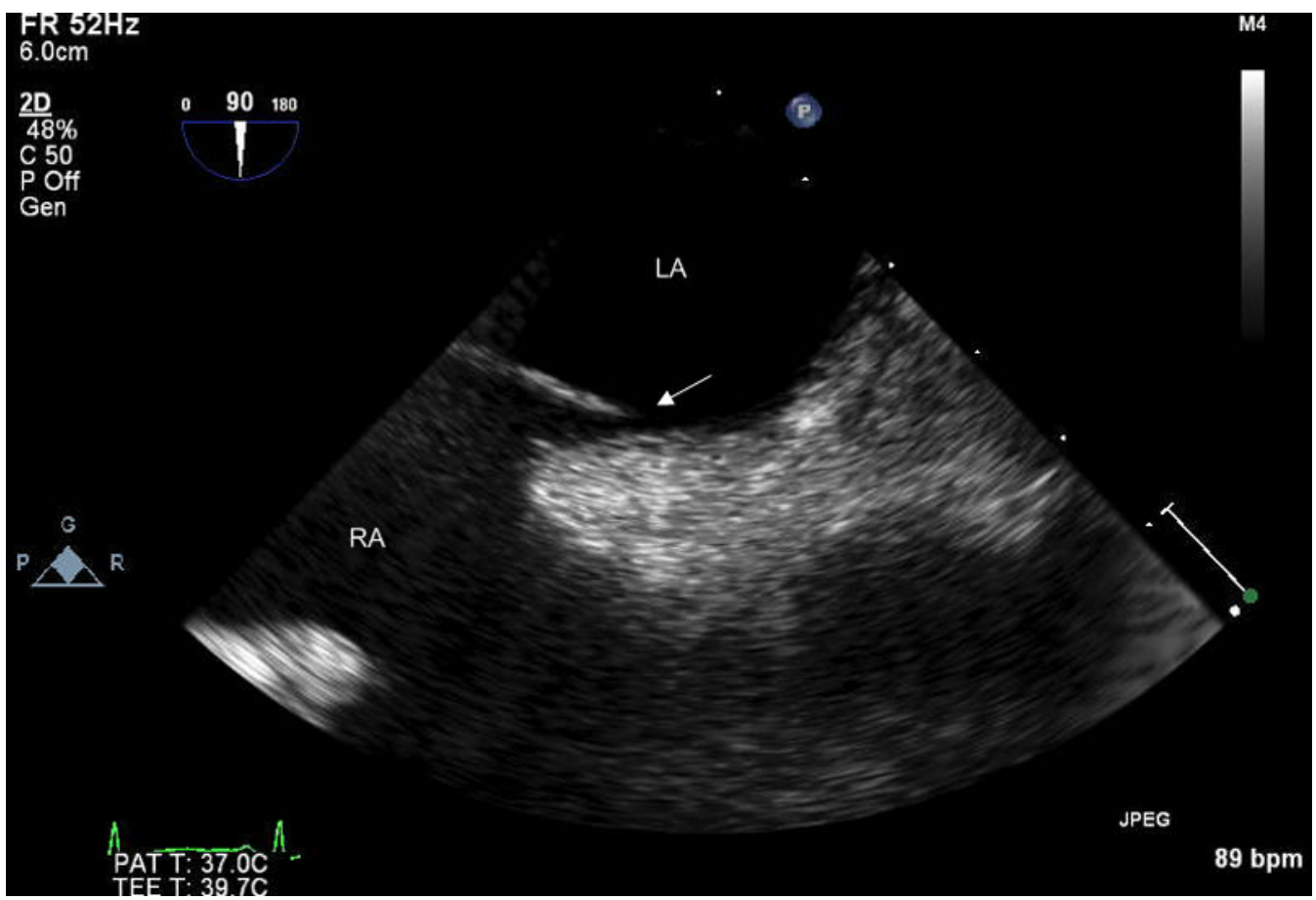

Figure 3.

Direct visualization of PFO by TEE. A separation (arrow) is seen between septum primum and septum secundum.

$\mathrm{LA}=$ left atrium; $\mathrm{RA}=$ right atrium 


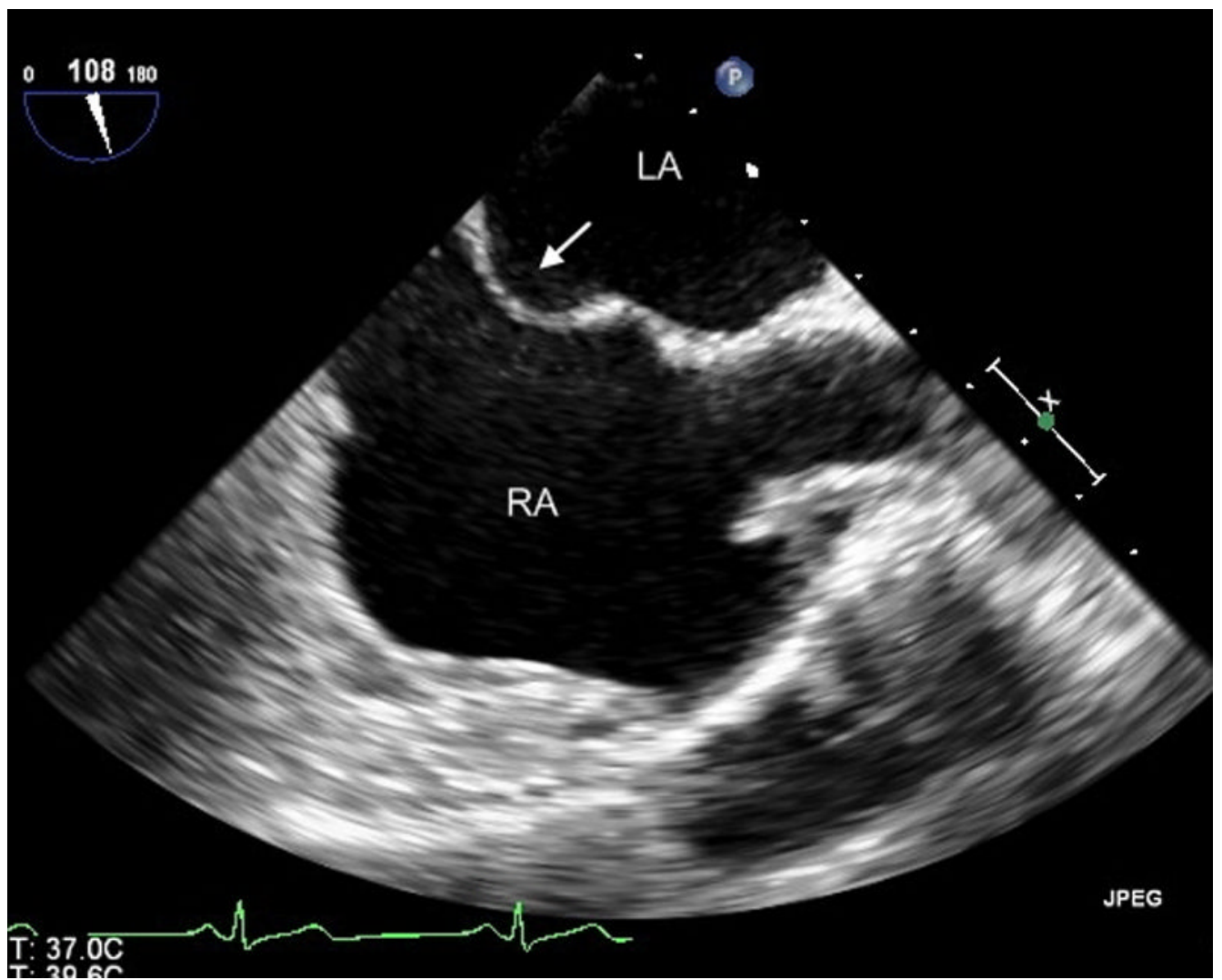

Figure 4.

Visualization of atrial septal aneurysm (ASA) by TEE. Protrusion of the atrial septum towards the right atrium is visible (arrow).

$\mathrm{LA}=$ left atrium; $\mathrm{RA}=$ right atrium 


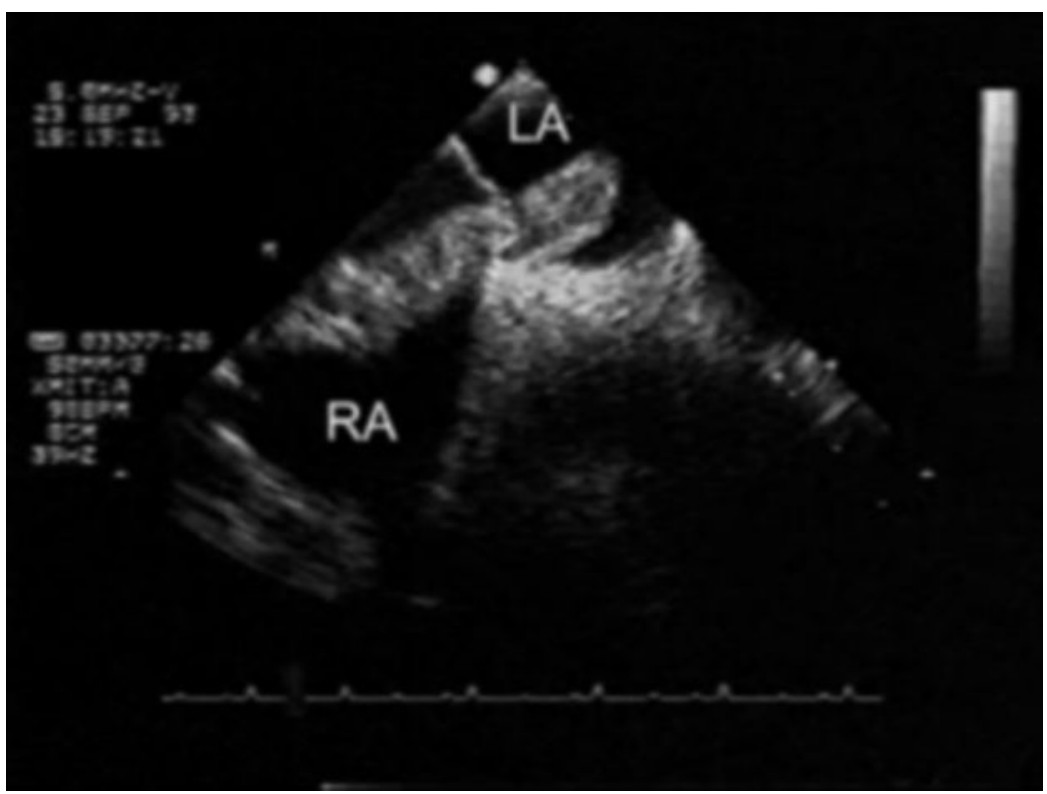

Figure 5.

Visualization by TEE of large thrombus crossing the PFO (arrows). $\mathrm{LA}=$ left atrium; $\mathrm{RA}=$ right atrium 


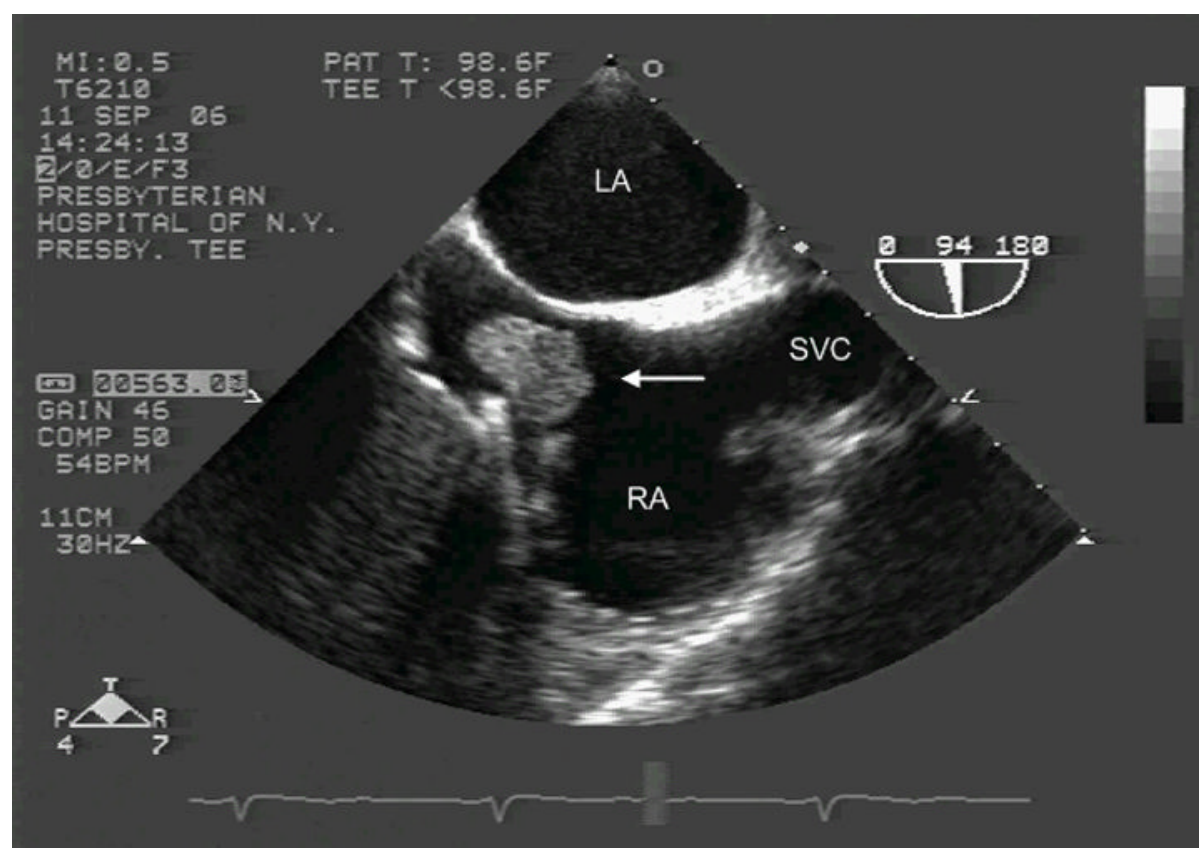

Figure 6.

Visualization by TEE of large thrombus (arrow) on the Eustachian valve.

$\mathrm{LA}=$ left atrium; RA = right atrium; $\mathrm{SVC}=$ superior vena cava 


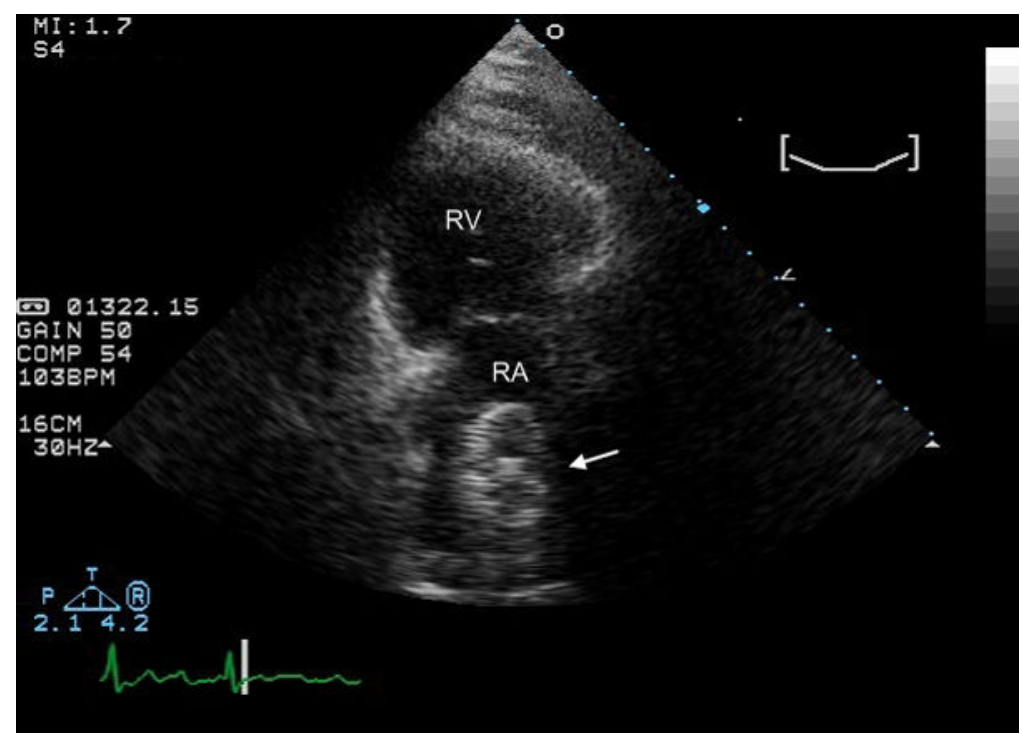

Figure 7.

Visualization by TTE (long axis view) of a PFO closing device. $\mathrm{RV}=$ right ventricle; $\mathrm{RA}=$ right atrium 


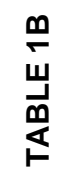

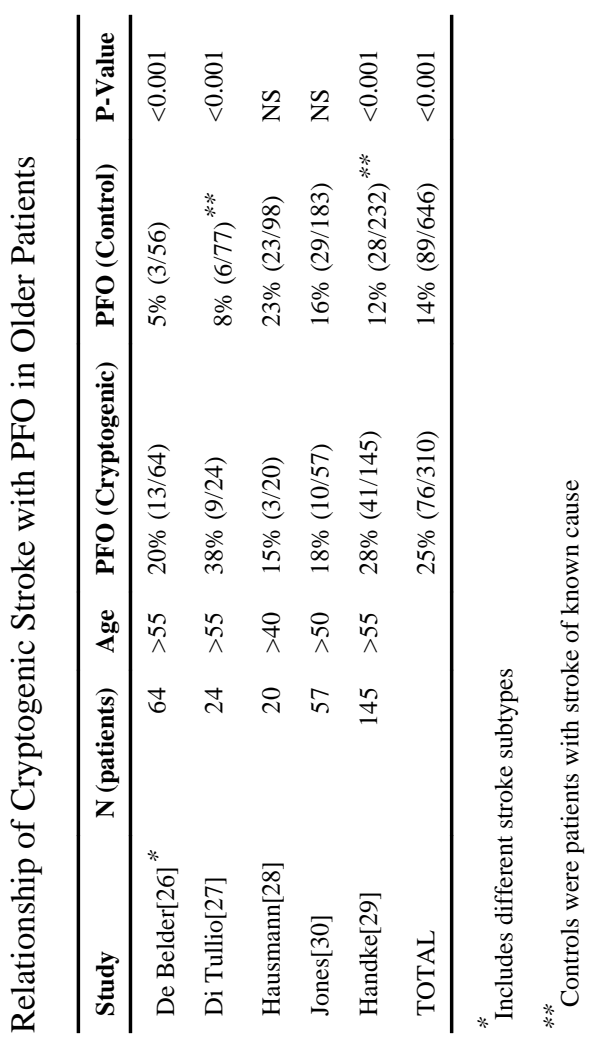

